\title{
The Liberal Peace and Conflictive Interactions: The Onset of Militarized Interstate Disputes, $1950-78$
}

\author{
Bernadette M.E. Jungblut \\ Department of Political Science, University of Central Florida \\ Richard J. Stoll \\ Department of Political Science, Rice University
}

Over the past few years, there has been an increasing focus on the connection at the dyadic level between democracy, interdependence, and international conflict. This has led to some contention, with scholars taking different positions on both substantive and methodological matters. This article seeks to advance this literature by building explicitly on the work of Oneal $\&$ Russett. It adds an additional facet to this literature: exploring the impact of conflictive interactions on the chances of a dyad experiencing conflict. A conflictive interaction is the presence of a conflict below the level at which military force is used. The question is whether the issue at stake in a conflictive interaction influences the chances of the dyad experiencing a militarized interstate dispute (MID). The scope of the research is all dyads from 1950 to 1978, with observations at the quarter-year. Results are generally consistent with Oneal \& Russett. However, there are several differences. First, the effect of joint democracy, while negative, is not statistically significant (this may be an artifact of our research design). Second, the coefficient for the higher trade-to-GDP ratio, while positive as in their work, is statistically significant here. But trade does reduce conflict (as embodied in the lower trade-to-GDP ratio) even when including the 'peaceyears' correction for temporal dependence. As for the impact of issue area, conflictive interactions involving issues of 'high politics' increase the chances of a dispute. Thus, elements of both 'high politics' and the liberal peace have independent impacts on the chances of an MID outbreak.

\section{Introduction}

In recent years, the quantitative international relations literature on the connection between the domestic environment and foreign policy decisionmaking has gone beyond its original focus on the democratic peace. ${ }^{1}$

\footnotetext{
${ }^{1}$ The literature on the democratic peace is extensive. Studies that support the finding that democracies do not fight democracies include Bennett \& Stam (2000), Bremer (1992, 1993), Dixon
} 
One recent addition to this literature is a growing number of studies on the 'liberal peace $^{2}$, the connection between democracy, interdependence, and international conflict. These studies of political economy are based on a more elaborate conception of the connections between states that are relevant to their conflict behavior. In this article, we introduce (more properly, reintroduce) another factor in the relationship between states that we believe can play an important role in the chances of two states engaging in a significant conflict short of war: the presence of a contentious issue between the states.

While the notion of issue area received much attention in the quantitative foreign policy literature of the 1960s and 1970s, interest in the concept then declined. But periodically, the idea that issues are an important aspect of interstate relations has been resurrected. For example, Mansbach \& Vasquez (1981) argued that international relations scholars should shift their focus 'from the issue of power to the power of issues'. ${ }^{3}$ Despite attempts to refocus attention on the importance of issues, Levy (1989:227) notes that 'relatively little attention has been given to the actual issues involved in the processes leading to war ... [although] it is recognized that some interests and some issues are more vital than others and more likely to lead to war than are conflicts over other issues'.

We believe that integrating the concept of issue area into the current research on the liberal peace is a logical extension. It moves us one more step down the road towards a more complete conception of the linkages and interactions between states that play a significant role in their conflict behavior. In this article, we conduct a preliminary study using information from the COPDAB dataset to explore the utility of issue area in predicting the onset of militarized interstate disputes between countries during the time period 1950-78.

\section{Issue Areas: From Typologies to Events Data}

The concept of issue area or issue arena in the international relations literature dates back at least to the early 1960s, initially focusing on developing typologies of public policymaking issues. We provide brief overviews of four of the better-known classification schemes.

\section{Lowi}

Lowi's (1964: 689) scheme places public policy into one of three categories: distribution, regulation, and redistribution. The key differences across these issue

(1993, 1994), Doyle (1986, 1997), Lake (1992), Maoz \& Russett (1993), Morgan \& Campbell (1991), Morgan \& Schwebach (1992), Oneal et al. (1996), Oneal \& Russett (1997, 1999a,b,c), Owen (1994), Ray (1993), Rummel (1983, 1985), Russett (1993), Russett,

Oneal \& Davis (1998), and Small \& Singer (1976). A second set of studies disputes this finding (although typically these studies conclude that the apparent democratic peace is due to some other factor).

These studies include Farber \& Gowa (1995), Gartzke (1998), Gowa (1994, 1999), Layne (1994), Oren (1995), and Spiro (1994).

2 In particular, see Journal of Peace Research 36(4), the July 1999 special issue on trade and conflict.

${ }^{3}$ As cited by Levy (1989: 301). 
arenas are their 'impact or expected impact on the society' and the extent or degree to which the political goods could be divided up among the interested parties. Each issue arena is characterized by a distinct 'political structure, political process, elites, and group relations' (Lowi, 1964:689-690).

Distributive issues can be disaggregated readily and entail pork barrel legislation and the process of log-rolling. Regulatory issues (such as the enactment of fair labor standards) are more difficult to disaggregate because general rules or laws are designed to be applicable to entire economic sectors. Redistributive issues (such as taxes or welfare programs) affect even broader segments of society, 'approaching social classes' (Lowi, 1964: 690-691). Lowi's primary illustrative example is a description of how United States trade policymaking was a distributive issue area prior to 1962 (with tariffs and quotas dispensed to virtually all requesting parties/firms) and a regulatory issue area thereafter (when the president was empowered to deal across entire economic sectors).

In a later treatment, Lowi (1967: 314-315, 324-325) argues that foreign policy decisionmaking also could be treated as an issue area.

\section{Rosenau}

Rosenau (1966: 161) defines an issue area as consisting of

(1) a cluster of values, the allocation or potential allocation of which (2) leads the affected or potentially affected actors to differ so greatly over (a) the way in which the values should be allocated or (b) the horizontal levels at which the allocations should be authorized that (3) they engage in distinctive behavior designed to mobilize support for the attainment of their particular values.

For Rosenau (1966: 154), how states behave vis-à-vis other state is largely a function of the 'nature of the issue'. He provides a four-part typology of issue areas based on the values over which states might differ or disagree: territorial; status; human resources; and non-human resources (Rosenau, 1966:162). Each of these four issue areas can be differentiated based on whether the allocation of values (ends) and the process by which these values are to be allocated (means) are tangible or intangible (Rosenau,1966: 165). For Rosenau (1966: 166), tangibility entails something physical and/or material. Tangible ends are those values that can be photographed, and tangible means are those allocation processes that involve the expenditure of money.

Rosenau (1966: 164) provides examples to illustrate his typology. The East/West confrontation over Berlin is an example of a territorial issue, categorized by tangible ends (e.g. the territory itself) and intangible means (e.g. diplomatic persuasion). The disagreement over the admittance of the People's Republic of China to the United Nations (and, consequently, what to do about Taiwan) is an example of the status issue area, with intangible ends (e.g. diplomatic recognition) and intangible means (e.g. diplomatic negotiation/bargaining). The human resources issue area includes policies that states or inter- national organizations make regarding population growth; this involves intangible ends (e.g. the choice of the number of children) and tangible means (e.g. funding educational programs regarding population control). The non-human resources issue area includes East/West trade during the Cold War; it is categorized by both tangible ends (e.g. imported and exported goods) and tangible 
means (e.g. foreign exchange).

\section{Zimmerman}

Zimmerman (1973) combines insights from the work of Lowi $(1964,1967)$ discussed above and Wolfers (1962: 3-35) to produce a 'paradigm of foreign-policy processes' based on a two-dimensional categorization. One dimension is whether or not policy is 'perceived to be symmetrical in its impact on politically relevant domestic political actors', and the other dimension is whether or not the 'political goods at issue [are] exclusively tangible' (Zimmerman, 1973: 1208). Three of the resulting issue areas are the same as Lowi's. If the domestic impact is symmetrical, and the political goods are tangible, the issue area is distributive. If the domestic impact is not symmetrical, and the political goods are tangible, regulation is the issue area. Finally, if the domestic impact is not symmetrical and the political goods are not tangible, the issue area is redistributive. Zimmerman argues that foreign policy can fall into any of these three areas. ${ }^{4}$

The fourth issue area is distinct from Lowi, and is exclusively the domain of foreign policy. The domestic impact is symmetric, and the political goods at issue are not exclusively tangible. Zimmerman asserts that this issue area represents both the pole of power and the pole of indifference from Wolfers. The pole of power consists of those issues that threaten the existence of the state. The pole of indifference contains issues of minor importance. According to Wolfers, issues located at both of these poles can be expected to call forth unitary rational actor models of state behavior, and do not involve domestic politics; later theorists of international relations might suggest that the pole of indifference belongs to bureaucracies and organizations, and that actions which are taken may not be the result of a rational process.

\section{Mansbach \& Vasquez}

Mansbach \& Vasquez (1981) and Vasquez (1983) provide some tests of the various issue typologies using an events dataset they developed that covered event interactions from 1949 to 1975 for the United States and West Germany. In the 1981 article, they test several issue typologies. They conclude that Rosenau's is the best means of classifying issues (to predict conflict and cooperation from the tangibility of ends or means), but that all typologies are 'deficient' (Mansbach \& Vasquez, 1981: 41). In his 1983 follow-up, Vasquez tested additional implications of Rosenau's typology. He found that the typology had only a moderate ability to predict conflict and cooperation.

\section{A Recurring Theme}

There is a significant amount of theoretical work on issue areas in international relations. Although, as noted, the quantitative work that has attempted to validate one

\footnotetext{
${ }^{4}$ Lowi believes that the redistributive issue area is exclusively domestic. But Zimmerman (1973: 1209) argues that '[I]imited wars are distinctively asymmetrical in their domestic political consequences', and, like all wars, the political goods are not exclusively tangible.
} 
or another of these schemes has not produced strong findings, scholars keep returning to issue area as a way to understand and organize foreign policy behavior. Why? The answer is the one offered by Levy (1989: 227) and noted above: scholars find it intuitively plausible that some issues are more vital than others, and that these types of issues are more likely to lead to serious conflict. We agree, and believe that the concept of issue area can be usefully incorporated into the research program on the liberal peace.

\section{From Issue Areas to Events Data}

The classic works on issue areas that we have discussed all begin with some sort of over-arching framework that places issues in a theoretical context. In this article, our approach is quite different. We use the categorization of issues taken from Azar's Conflict and Peace Data Bank (COPDAB). COPDAB is one of the most widely known and used event datasets. It consists of approximately 500,000 events coded from about 70 international sources on 135 countries. Over 100 individual event types are coded, and the daily events that occur between two states are classified according to the 'primary content of the event' (Azar,1993: 10); further detail on COPDAB is supplied below in the discussion of variables and in Appendices B and C. 5

The COPDAB dataset classifies each event into one of seven issue categories (plus an eighth 'other or residual' category). This is the issue scheme (described in depth in Appendix B) that we use in the analyses in this article. We adopt it for several reasons. Most obviously, events in the COPDAB dataset are already classified according to this scheme. But there are two other reasons that we use it. First, we find the scheme more straightforward than the others that we have discussed. Issues in COPDAB are categorized by substantive area (for example, economic relations or military and strategic relations). The other schemes are more conceptual, attempting to include information about the process by which issues are resolved, or the impact of this resolution. Since we are beginning to explore the impact of issue, we prefer the simpler scheme. Second, the results of Mansbach \& Vasquez suggest that the other schemes do not have a great deal of ability to discriminate between conflict and cooperation. Since the goal of our study is to predict the onset of disputes, we feel that the more direct COPDAB issue scheme may better discriminate those circumstances in which disputes occur. The major limitation of this dataset is that the collection ends at the end of 1978, while the Oneal \& Russett (1999a) study on which we base our work ends in 1992. Unfortunately, there is no feasible way to extend the dataset (most importantly, the coding of issue area) in time so that our temporal domain is comparable to that of Oneal \& Russett (1999a). Nevertheless, we believe that the ability to integrate issue area into our research out- weighs the disadvantages of the shortened time-frame that we can explore.

\footnotetext{
${ }^{5}$ It is interesting to note that in Azar's introduction to the COPDAB codebook, he suggests a connection (albeit a quite tentative one) to Lowi's, Rosenau's, and Zimmerman's notions that issue areas can be differentiated in terms of their impact on domestic society: 'Every day we hear or read about events that happen within countries or between them ... The past and present continue to unfold for us, and we persist in searching for simplified procedures to describe and interpret their developments, and to evaluate them in terms of their impact on our personal lives and on the community of which we are a part' (Azar, 1993: 4, emphasis added).
} 


\section{Theoretical Framework: The Liberal Peace, Conflictive Interactions, and Issue Areas}

Since we add the concept of issue area to the work of Oneal \& Russett (1999a), we rely on their theoretical framework to define and justify the other factors in our study that are hypothesized to have a significant impact on the probability of a militarized interstate dispute within a dyad.

\section{Joint Democracy and Conflict}

The literature on the democratic peace is well known and has consistently produced finding that democracies do not fight wars against other democracies, so it will not be discussed at any length here. More recently, researchers have examined the relationship between regime type and forms of militarized conflict short of war. Consistent with the previous literature on the democratic peace, we see two arguments for why a pair of democracies is unlikely to engage in MIDs. First, the normative explanation: in democracies, domestic conflicts are usually resolved in a peaceful manner, and this resolution process will carry over internationally when two democracies deal with one another. Second, the structural explanation: a variety of structural constraints make it difficult for two democracies to mobilize both of their societies for war.

\section{Trade and Conflict}

The results of research on the relationship between international trade and interstate conflict contain a confusing and contradictory array of theoretical propositions. Since that work is particularly important to our efforts, we devote significant time to discuss the theoretical and empirical work on this topic. Propositions that trade inhibits conflict draw from a variety of research traditions and methodologies including, but not limited to: functionalism (e.g. Haas, 1958; Mitrany, 1946); political and/or economic liberalism (e.g. Kant, 1795; the Manchester School); theories of international exchange (e.g. Rosecrance, 1986); and expected utility maximization (e.g. Polachek, 1980). These scholars assert that the economic benefits of trade will constrain states from engaging in interstate conflict because of the harm to the gains from trade that such conflict will inflict. ${ }^{6}$

Scholars who argue that the likelihood of interstate conflict increases as a function of economic interdependence focus on the costs that trade inflicts on states, particularly states that are 'more dependent' on those trade relations. These scholars draw from: imperialism and expansionism (e.g. Hobson, 1902; Lenin, 1939); mercantilism, Marxism-Leninism, neoimperialism, neomercantilism, and dependency theory (e.g. Cardoso \& Faletto, 1979); resource scarcity models (e.g. Choucri \& North, 1975); theories of economic statecraft (e.g. Hirschman, 1945); relative gains research, neorealism (e.g. Waltz, 1979); and examinations of the negative security externalities associated with economic interdependence (e.g. Gowa, 1994).

The literature asserting that economic interdependence has no significant effect on international conflict follows primarily from traditional realist thought distinguishing between the 'high politics' of security issues and the 'low politics' of

\footnotetext{
${ }^{6}$ This assumption has recently been questioned by Barbieri \& Levy (1999).
} 
economic concerns (e.g. Buzan, 1984; Levy, 1989; Morgenthau, 1985; Ripsman \& Blanchard, 1996). These scholars argue that neither the benefits nor the costs of international trade are sufficient to change foreign policy decisionmaking regarding security issues.

Empirical examinations of the trade- conflict relationship have also produced contradictory results. Several examinations have found support for the liberal hypothesis that international trade reduces the likelihood of interstate conflict. ${ }^{7}$ Other scholars, however, have suggested that this may not always be the case. ${ }^{8}$ To date, over 40 studies including large- $\mathrm{N}$ quantitative analyses, formal- theoretical examinations, and smaller-N qualitative investigations have been conducted. But, according to one review of the literature, 'the extant formal and empirical research on the relationships between trade and international conflict raises more questions than it answers' (McMillan, 1997: 52), and a more recent review still finds that 'the growth in scholarship has done little to resolve the basic question of whether trade promotes peace. Taken as a whole, statistical studies of the trade-conflict relationship provide a mixed set of findings' (Barbieri \& Schneider, 1999: 394).

The most relevant set of studies for our work are the studies that evaluate the 'liberal peace'. Here, too, the results are mixed. While some of the most recent large$\mathrm{N}$, quantitative research finds strong support for the economic liberal hypothesis (Hegre, 1998; Oneal \& Russett, 1997, 1999a,b,c; Russett, Oneal \& Davis, 1998), these results have been challenged by Barbieri (1998), Beck \& Tucker (1996), and Beck, Katz \& Tucker (1998). Barbieri concluded that international trade was positively associated with interstate conflict, and Beck, Katz \& Tucker (1998: 1278) asserted that 'Oneal \& Russett's evidence in support of the liberal economic peace is an artifact of their incorrect assumption of temporal independence'. While we expect the debate on the liberal peace to continue, we believe that it is important to include factors to represent its potential impact on our analysis; thus, we include measures of trade as a percentage of GDP in our models.

\section{Conflictive Interactions}

Although there are over 2,000 cases in the Militarized Interstate Dispute dataset (Jones, Bremer \& Singer, 1996: 167), the fact of the matter is that these are relatively rare and extreme forms of conflict. While realists would have us believe that the international system is full of serious conflict, and states must always be prepared to resort to force, the simple fact is for most dyads of states on most days, the threat, display, and use of military force is not actively being considered by either state. States in a dyad can have a number of issues over which they disagree, and each may seek to alter the preferences of the other through a variety of means. But many (probably most) of these issues will be handled without invoking the specter of military force.

In the same way that we do not expect wars to arise out of the clear blue (there are likely to be strong traces of a conflict prior to the onset of war), ${ }^{9}$ we expect that

\footnotetext{
${ }^{7}$ See, for example, Domke (1988), Gasiorowski \& Polachek (1982), Hegre (1998), Oneal et al. (1996), Oneal \& Russett (1997, 1999a,b,c), Polachek (1980), and Russett, Oneal \& Davis (1998).

${ }^{8}$ See, for example, Barbieri (1996a,b, 1998), Barbieri \& Levy (1999), Copeland (1996), de Vries (1990), Gartzke (1998), Gasiorowski (1986), Hirschman (1945), Sayrs (1989), Papayoanou (1996), and Ripsman \& Blanchard (1996).

${ }^{9}$ This in fact was one of the original reasons for collecting the MID data: to provide a list of conflicts
} 
conflicts involving the threat, display, or use of military force (i.e. MIDs) will have analogous precursors. We call these sub-MID conflicts conflictive interactions. A conflictive interaction is a situation in which two or more states have different preferences over one or more issues, have expressed these different preferences through one or more hostile actions, but have not explicitly threatened, displayed, or used military force. We hope to gain some insight into the circumstances under which these conflicts will escalate to MIDs. For this article, we will identify the presence of a conflictive interaction by the presence of hostile actions within a dyad of states. We will also investigate whether some of the issues involved in conflictive interactions are more likely than others to escalate to the onset of an MID.

\section{Data and Methods}

We begin with the model specification of Oneal \& Russett (1999a), introducing several changes for the purposes of our investigation. ${ }^{10}$ Like Oneal \& Russett, we study the dyad. But our temporal aggregation is the quarter-year. We identify conflictive interactions from the characteristics of a single event and observe whether these events are quickly followed by the onset of an MID. To avoid the problem of incorrect time ordering (i.e. the conflictive interaction occurs after the onset of the MID), we have to lag the conflictive interactions. A year strikes us as being too long a period of time between the onset of a conflictive interaction and the onset of a dispute ${ }^{11}$ since we want to presume some connection between the two. Clearly, some temporal aggregation of less than a year is highly desirable. On the other hand, a great deal of the data we will use in this analysis is only available on the yearly level, so an extremely small time slice (for example, a week) is likely to prove unsatisfactory. Our compromise for this article is to use a quarter-year as the time unit for this study ${ }^{12}$ and predict from variables in the previous quarter $(t-1)$ to whether a dyad experiences the onset of a MID in the next quarter ( $\mathrm{t}$ ). As well, we are limited in our analysis to 1950 through 1978, due to our reliance on the COPDAB dataset.

\section{Dependent Variable}

Our dependent variable is a dichotomous measure of the onset of a militarized inter-state dispute between States A and B in quarter $\mathrm{t}^{13}$ This variable is coded 0 if no militarized dispute between States A and B started in quarter $t$, and coded 1 if a dispute between States A and B commenced in quarter t. We do not code any subsequent quarter-years of multi-quarter disputes.

out of which war could have occurred, and examine the differences between those that ended in war and those that did not.

\footnotetext{
${ }^{10}$ We are grateful to Oneal \& Russett for providing their data via their website: http://www.yale.edu/unsy/democ/democ1.htm.

${ }^{11}$ Note that in the extreme when using a lag of one year, the conflictive interaction could take place on 1 January of year $t-1$, and the MID could begin on 31 December of year $t$, although the actual temporal distance is likely to be far smaller.

${ }^{12}$ The choice of a quarter-year lag structure will be reassessed in future analyses. In particular, we are contemplating using a half-year lag.

${ }^{13}$ See Jones, Bremer \& Singer (1996) for a full description of these data.
} 


\section{Independent Variables}

Variables from Oneal \& Russett As noted above, we build explicitly upon Oneal \& Russett (1999a), including the following variables from their work: lower trade as a proportion of GDP; higher trade as a pro- portion of GDP; ${ }^{14}$ joint democracy; contiguity; logged distance between the capitals; the presence of a major power in the dyad; the presence of an alliance between the members of the dyad; and the logged capability ratio of the dyad (larger divided by smaller). All these variables are lagged one time unit ${ }^{15}$ and are described in Appendix A. This set of variables allows us to examine the impact of the liberal peace on the involvement of the dyad in militarized interstate disputes. Our expectation is that these variables will have the same impact as reported in Oneal \& Russett (1999a).

Conflictive Interactions and Issue Areas A major focus of this article is whether our ability to predict the onset of MID involvement by a dyad can be enhanced if we know whether or not the dyad is engaged in a conflictive interaction. To explore this question, we need a way to determine if a dyad is involved in a conflict at a level below that which is captured in the MID dataset, as well as some indication of the issue(s) involved in the conflict.

We rely on Azar's Conflict and Peace Data Bank (COPDAB) for this information. COPDAB is a daily events data collection. As noted above, data have been coded on about 135 countries from international media sources on about 100 event types. The time- span is from 1 January 1948 through 31 December 1978 (see Azar, 1980, 1993). COPDAB taps a level of interaction between states that can be well below that of the MID data. This can be clearly seen by examining the 15-point international event scale used in the COPDAB data to classify the event types (see Appendix C) and comparing it to what is contained in the MID data: the threat, display, and use of force (Gochman \& Maoz,1984; Jones, Bremer \& Singer, 1996).

We wish to identify those events that indicate conflictive interactions between states. Conflictive interactions indicate that states are engaged in a significant disagreement, but that they have not yet escalated that dis-agreement to the level of threat, display, or use of force. Examining the description of each scale value in the COPDAB data (Appendix C), we believe that the following scale values correspond to our notion of conflictive interactions:

(10) Strong verbal expressions displaying hostility in interaction

(11) Diplomatic-economic hostile actions

(12) Political-military hostile actions

We do not include COPDAB events that received a scale score ranging from 1 through 7 because these are primarily cooperative events. Events scored 7 include 'minor official exchanges, talks, or policy expressions- mild verbal support'. Events that were

\footnotetext{
${ }^{14}$ Oneal \& Russett refer to these two variables as lower trade dependence and higher trade dependence. We will refer to these variables as lower and higher trade as a proportion of GDP. ${ }^{15}$ The Oneal \& Russett dataset is at the yearly level. Our dataset is organized on the quarter-year level. For our analysis, lagging means that for any observation in our dataset in year $t$, the Oneal \& Russett variables are lagged to the year $t-1$. That is, for each case in our dataset in every quarter of year $t$, the Oneal \& Russett variables take on the values for year $\mathrm{t}-1$.
} 
scored 8 are not included because they are 'neutral or non-significant acts'. Events that were scored 9 are not included; these events are "mild verbal expressions displaying discord in interaction', and, as such, we do not believe them to be sufficiently contentious. Events that received a scale score of 13, 14, or 15 are not included because they involve actions using military force.

The COPDAB data also contain a coding for the primary issue area of each event. We will examine the effects of each issue type separately. We create dummy variables for each of the seven issue area types coded by COPDAB. Each of these variables is coded 1 if a dyad experienced a conflictive interaction on that issue (i.e. one or more events coded for that issue with a scale score between 10 and 12) in quarter $\mathrm{t}$, and coded 0 if the dyad did not. These variables are all lagged one quarter. The seven issue areas are: (1) symbolic political; (2) economic; (3) military and strategic; (4) cultural and scientific; (5) physical environment and natural resources; (6) human environment, demographic, and ethnic affairs; and (7) political order, law, and organization. These are all described in detail in Appendix B. Table I displays the descriptive statistics for the variables used in the analysis.

\section{Methodology}

Due to our dichotomous dependent variable and the cross-sectional, time-series nature of our data, we utilize a logit specification, allowing for the possibility of both temporal and cross-sectional dependence. To take temporal dependence into consideration, we follow the procedure advocated by Beck \& Tucker (1996) and Beck, Katz \& Tucker (1998). We create a variable for each dyad reflecting the number of quarters $^{16}$ since the last MID, and a set of three natural cubic spline variables as a substitute for temporal dummy variables. ${ }^{17}$ During the estimation procedure, we specify that each non-directed dyad is a group to assess cross-sectional effects, and employ Huber's robust standard errors. ${ }^{18}$

\section{Findings ${ }^{19}$}

\footnotetext{
${ }^{16}$ This variable, called 'peaceyears', is expressed in terms of proportion of a year. For example, if peaceyears takes on a value of .75, it has been three-quarters since the onset of a MID for that particular dyad.

${ }^{17}$ In the recent literature on trade and conflict, there is discussion of using other techniques such as the General Estimating Equation, or GEE (Oneal \& Russett, 1999a: 427), or a 'smoothing spline in duration' (Beck, 1999: 3). At this time, however, there does not appear to be a consensus regarding which technique to use. Further, our lack of access to S-PLUS (used by Beck, 1999) limits our choice of analytic technique. Thus, we employ the logit approach described above and use Stata for all of our analyses.

${ }^{18}$ All estimation was done using Stata 6.0 with the binary time-series cross-section data analysis utility developed by Beck, Katz \& Tucker (1998).

${ }^{19}$ Because we do not have an extremely strong theory, it seems prudent to explore some alternative formulations to give us greater confidence in our findings. We conducted the following runs, both with and without the issue area dummies:

(1) Alter the level of the dependent variable; disputes that reach at least the display of force, disputes that reach at least the use of force level, disputes that end in war.

(2) Alternative lag structures; lag all variables 2 periods, 3 periods, and 4 periods. Include all lags in the same equation (i.e. 1 period, 2 periods, 3 periods, and 4 periods, all in the same equation).
} 
Our findings (see Table II) are largely consistent with those of Oneal \& Russett (1999a). ${ }^{20}$ We will discuss the control variables, then those variables that represent the concepts of the liberal peace: trade as a pro- portion of GDP and joint democracy.

If the dyad consists of contiguous countries, it is more likely to become involved in a dispute. This finding is reinforced by the negative relationship of the distance between capitals and the onset of dispute. Both variables make it clear that countries that are close to one another are more likely to become involved in disputes.

The variable representing capability (the natural $\log$ of the ratio of the capability of the more powerful state to the weaker state) is also significant. The higher the ratio (the greater the disparity in capability in the dyad), the less likely the dyad is to become involved in a dispute. This is consistent with the majority of empirical findings about the relationship between the capability ratio and conflict.

As with the Oneal \& Russett (1999a) study, dyads containing a major power are more likely to experience a dispute than dyads that do not contain one. As well, dyads that are allied are less likely to engage in a dispute.

Turning to the two indicators of trade as a percentage of GDP, our analysis produces the same signs as Oneal \& Russett (1999a). The variable with the lower value for trade as a percentage of GDP has a negative sign, indicating that this reduces the chances of a dispute. This is interesting because Oneal \& Russett (1999a) do not find that trade renders conflict significantly less likely in their analysis of all dyads using the Beck, Katz \& Tucker 'peaceyears' correction. ${ }^{21}$ As well, Beck \& Tucker (1996) and Beck, Katz \& Tucker (1998) also found that trade was not statistically significantly related to conflict when the 'peaceyears' correction was included. Our finding about the lower trade- to-GDP ratio in the dyad deserves some future exploration, although our larger number of cases undoubtedly has an influence on the significance level of our results.

As with Oneal \& Russett, the coefficient for the larger value of trade as a percentage of GDP is positive. In our analysis, this coefficient is statistically significant, while this is not the case in the analysis of Oneal \& Russett (1999a), indicating that asymmetric trade or dependency increases the danger of conflict (Oneal $\&$ Russett, 1999a: 427). However, since we have over five times the number of cases of Oneal \& Russett, this difference is not too surprising.

We also find a negative effect for joint democracy, which is consistent not only with Oneal \& Russett, but with the preponderance of the literature on the democratic peace. But despite the extremely large number of observations, the effect is not

(3) Alternative operationalization of conflictive interactions; code only scale values 10 and 11 as indicative of conflictive interactions.

(4) Alter the level of the dependent variable and use alternative operationalization of conflictive interactions.

(5) Alternative lag structures and alternative operationalization of conflictive interactions.

Taken together, these alternative specifications produce results that are very similar to the results reported in the body of the article. Copies of the results are available from the second author.

${ }^{20}$ See Oneal \& Russett (1999a: 433, Table II), but note that there were errors in that table, and a corrected version was published in the next issue of Journal of Peace Research, 37(1).

${ }^{21}$ See Oneal \& Russett (1999a: 433, Table II, first column). They do, however, find this effect in their analysis of all dyads employing the General Estimating Equation (GEE) and also in their analyses of only politically relevant dyads, employing first, the 'peaceyears' correction of Beck, Katz \& Tucker (1998), and second, the GEE. 
statistically significant. While there may be a substantive explanation for this, the lack of significance may be a consequence of shifting the temporal aggregation from the year to the quarter-year.

Consider the following example illustrated in Table III. Suppose we have 100 dyad-year observations, and classify each observation in terms of whether it is a democratic dyad or not, and whether it experiences a MID or not. Assume that the dyads are distributed as shown on the left side of Table III: there are 10 dyad-years with democracy and no MID, 70 dyad-years with no democracy and no MID, and 20 dyad-years with no democracy and an MID. The phi coefficient for this table ${ }^{22}$ is .167 . Now take the same data and use the quarter-year as the temporal aggregation. This would quadruple the number of observations. Each MID belongs in a quarter of a year, so the number of no democracy-MID dyads remains the same. But each of the remaining quarters of that year adds an additional 3 no democracy-no MID observations, so that cell increases to 340 . Similarly, the number of democracy-no MID observations quadruples to 40 . The new table is shown on the right side of Table III. Notice that although the connection between democracy and MID occurrence has not changed, using a finer grain temporal aggregation reduces the fit (as measured by phi) by just over $50 \%$.

The results of our second model, which includes the dummy variables for conflictive interactions, are presented in Table IV. The variables from Oneal \& Russett have effects very similar to those noted in Table II. However, in Table IV, while the effect of the dyad member with the larger proportion of trade-to-GDP is positive (as it was in Table II, contrary to the findings of Oneal \& Russett, 1999a but supporting the findings of Barbieri, 1996a), it just misses being significant at the usual .05 level. As we noted above, we find it a bit unusual to have coefficients fail to reach the standard level of statistical significance with such a large sample size. As before, the impact of joint democracy is to reduce the chances of conflict, but it is not statistically significant (although the level is closer to .05 than in the initial analysis). All of the variables associated with the correction for group duration nature of the data are significant except for the third spline variable.

Examining the conflictive interaction dummies, we find that two of them are significant: military and strategic relations; and political order, political relations, and law/organization. Full descriptions of both issue areas are contained in Appendix B, but a brief discussion here is in order. The military and strategic relations issue area involves a number of military acts that (because we restrict our attention to scale scores of 10 to 12) appear to fall below the level of an MID. The second issue area reflects 'the major political interactions between . . . countries' (Azar, 1993: 24). Thus, we find that the two issues that have a significant impact on the chances of a dyad

${ }^{22} \mathrm{Phi}$ is an analogue of Pearson's $r$ for two dummy variables (Jones, 1971: 128-130). 
becoming involved in a militarized interstate dispute are those that represent the traditional concerns of high politics. This is consistent with the perspective of realism; it is these issues that are most central to the traditional vital interests of the state, and there- fore most likely to lead to conflict.

We want to explore the impact of these two issues on the onset of an MID. As is well known, examining the coefficient values of a logit is not particularly useful, since these have no clear and direct interpretation. In addition, MIDs are rare events; there are over 620,000 quarterly observations in the dataset, but a dispute occurs in less than 800 of them.

To gain some understanding of the magnitude of the effects, we will calculate the relative risk or risk ratio (King \& Zeng, 2000:1) of a dispute when each of the two statistically significant types of conflictual interaction is present, versus the situation when neither is present, and the situation is 'typical'. Specifically, we calculate a baseline probability of a dispute. This is the predicted probability of a dispute when all non-issue variables take on their mean values and no conflictive interactions are present (i.e. all issue dummies have a value of 0 ). To calculate the relative risk of a dispute, given a conflictive military issue, we continue to hold all non-issue variables at their mean, add the impact of a conflictive military issue (i.e. set the value for that variable to 1), and calculate the predicted probability. Finally, we divide the probability with the issue present by the baseline probability; this is the relative risk. Table $\mathrm{V}$ shows the probabilities and the relative risks for the baseline and the two issues.

Table V demonstrates two things. First, the chance of a dispute in any 'normal' quarter-year is very small. Second, the presence of either a contentious military or political order issue clearly increases the chances of a dispute between the states of the dyad. In fact, as shown by the relative risks, each of these issues increases the chances of an MID occurring by about $75 \%$. This demonstrates that issues (at least certain issues) have substantively important effects on the outbreak of serious international conflict.

As a final effort to look at the impact of issues, trade, and joint democracy, we con- sider the interactions between the two significant 'high politics' issues and the three variables representing the liberal peace: the lower and higher ratios of trade-toGDP, and the dummy variable for joint democracy. ${ }^{23}$ Realists (e.g. Morgenthau, 1985;

\footnotetext{
${ }^{23}$ We also tried to estimate an equation with the interactions of the two trade-to-GDP ratios and joint democracy with all of the issue variables. However multi-colinearity among these interaction variables resulted in most of them being dropped from the estimation. In the future, we plan to try various other combinations of issues and interactions. Given the preliminary nature of this investigation, we felt it was important to concentrate primarily on those issues that were significant in the initial analysis.
} 
Waltz, 1979) might be willing to accept the notion that the elements of the liberal peace help to ameliorate the chances of conflict if the issue at stake was not important or vital to the national security of the state. However, realists would expect that the elements of the liberal peace should have no such pacific effects if the conflictive interactions were on issues that we associate with 'high politics'. One outspoken advocate of neorealism in post-Cold War Europe (Mearsheimer, 2002: 26) expressed it thus; first, with regard to the pacific impact of economic interaction:

States are not primarily motivated by the desire to achieve prosperity. Although economic calculations are hardly trivial to them, states operate in both an international political and an international economic environment, and the former dominates the latter when the two systems come into conflict. [italics added]

As for the impact of a democratic Europe on the prospects for peace, he argues that ' $[\mathrm{w}]$ hile the spread of democracy across Europe has great potential benefits for human rights, it will not guarantee peaceful relations among the states of post-Cold War Europe . . . The best hope for avoiding war in post-Cold War Europe is nuclear deterrence' (Mearsheimer, 2002: 30). In other words, when important issues are at stake, even the democracies of Europe will view their world through the lens of neorealism and rely on the threat of force in their foreign policies. In the context of our analysis, proponents of Mearsheimer's position would expect that the interactions between 'high politics' conflictive interactions and the liberal peace should work to reduce significantly the impact of the liberal peace variables.

In Table VI, we reran the equation reported in Table IV, adding interaction terms between the two significant issues and three variables of most substantive interest: the lower and higher ratios of trade-to- GDP, and the dummy variable for joint democracy. This produces a total of six new terms in the equation. In this analysis, none of these six interaction terms is significant. We see this as an interesting finding. Although this is only one analysis over a limited time period, the lack of statistical significance for any of the interactions serves to refute the arguments of the hardline realists such as Mearsheimer, and to lend support for the impact of the liberal peace, even in situations when 'high politics' should exert its maximum impact.

\section{Conclusion and Future Research}

Although the focus of our effort was the re- introduction of the concept of issue area and ascertaining whether it could aid in the prediction of conflict, we want to begin by noting how our results compare with other efforts to study the liberal peace. In particular, we compare our findings to those of Oneal \& Russett (1999a), since our study was modeled on their efforts. This discussion is based on the results of both 


\section{Table II and Table IV.}

The smaller trade-to-GDP ratio has a negative and significant impact on the onset of conflict. This finding is quite interesting given that we employ the correction for temporal dependence advocated by Beck \& Tucker (1996) and Beck, Katz \& Tucker (1998). Previous studies using all dyads as cases and the 'peaceyears' correction did not find a statistically significant impact for this variable. Of course, the increased number of cases in our study (versus Oneal \& Russett, 1999a) undoubtedly has something to do with this.

As with previous studies, we find that the larger trade-to-GDP ratio is associated with an increase in the chances of conflict. In Table II, which is the closest to a replication of Oneal \& Russett (1999a), this coefficient is significant. In Table IV, with issue area dummies added to the equation, the coefficient is not significant. Note the great disparity in the absolute value of the coefficients for the two trade-to-GDP ratios, suggesting that the smaller ratio has a far larger impact on the onset of conflict. Although the coefficient is significant in one of the tables, the fact that it is not in the other, combined with the much larger number of degrees of freedom in our study (versus Oneal \& Russett, 1999a), leads us to conclude that the differences between our results and Oneal \& Russett's are more apparent than real.

Although we find that joint democracy has a negative impact on the onset of con- flict, this impact is not statistically significant. This finding is unexpected and flies in the face of most of the studies that have examined the effect of joint democracy on conflict. Clearly, the problem is not the size of the sample. We see two possible expla- nations. First, the inhibiting effects of joint democracy may simply not extend to the escalation from conflictive interaction to dispute. As political scientists (and others) carry the exploration of the impact of democracy to greater and greater lengths, at some point we will probably find that democratic states are no different from others. Perhaps this study has simply reached that point. The second possibility was discussed earlier (see Table III and the associated discussion in the text). The lack of significance may be due to the impact of the quarter-year time aggregation used in this study. Additional work needs to be done to ascertain which of these explanations is correct.

And what of issue area? We find that conflictive interactions in which the issues are consistent with notions of 'high politics' are more likely to escalate to disputes. But there is no interaction effect if these issues are combined with the elements of the liberal peace. Although this is only a single study, we offer the following as an interpretation of these findings and guide for future work. States engaged in low-level conflict are subject to a variety of influences, some of which drive them towards escalation, and others of which act to restrain them from escalation. If there are elements of the liberal peace - strong economic connections, a sharing of democratic values - present in the dyad, these elements will dampen the chances of escalation. But at the same time, if the issues associated with the low-level conflict are critical to the countries (i.e. they involve military or political order issues), states are likely to escalate the conflict.

We think this is a useful point of departure. It suggests that states are attentive to the elements of the liberal peace, and also to the traditional concerns of high politics. 
We believe that the challenge that lies ahead is to synthesize a coherent theory that includes both of these elements. 


\section{References}

Azar, Edward E., 1980. 'The Conflict and Peace Data Bank (COPDAB) Project', Journal of Conflict Resolution 24(1): 143-152.

Azar, Edward E., 1993. Conflict and Peace Data Bank (COPDAB), 1948-1978. Third ICPSR Release. Ann Arbor, MI: Inter-University Consortium for Political and Social Research.

Barbieri, Katherine, 1996a. 'Economic Inter- dependence: A Path to Peace or a Source of Interstate Conflict?', Journal of Peace Research 33(1): 29-49.

Barbieri, Katherine, 1996b. 'Interdependence and the Characteristics of Conflict,1870-1992', paper presented at the Annual Meeting of the American Political Science Association, San Francisco, CA, 29 August-1

September.

Barbieri, Katherine, 1998. 'International Trade and Conflict: The Debatable Relationship', paper presented at the Annual Meeting of the International Studies Association, Minneapolis, MN, 18-21 March.

Barbieri, Katherine \& Jack S. Levy, 1999. 'Sleep- ing with the Enemy: The Impact of War on Trade', Journal of Peace Research 36(4):463-480.

Barbieri, Katherine \& Gerald Schneider, 1999. 'Globalization and Peace: Assessing New Directions in the Study of Trade and Conflict', Journal of Peace Research 36(4): 387-404.

Beck, Nathaniel, 1999. 'Trade and Conflict in the Cold War Era: An Empirical Analysis', paper presented at the Annual Meeting of the American Political Science Association, Atlanta, GA, 2-5 September.

Beck, Nathaniel \& Richard Tucker, 1996. 'Conflict in Space and Time: Time-Series-CrossSection Analysis with a Binary Dependent Variable', paper presented at the Annual Meeting of the American Political Science Association, San Francisco, CA, 29 August-1 September.

Beck, Nathaniel; Jonathan Katz \& Richard Tucker, 1998. 'Taking Time Seriously: TimeSeries-Cross-Section Analysis with a Binary Dependent Variable', American Journal of Political Science 42(4): 1260-1288.

Bennett, D. Scott \& Allan C. Stam, 2000. 'Research Design and Estimator Choices in the Analysis of Interstate Dyads: When Decisions Matter', Journal of Conflict Resolution 44(5): 653-685.

Bremer, Stuart A., 1992. 'Dangerous Dyads: Conditions Affecting the Likelihood of Inter- state War, 1816-1965', Journal of Conflict Resolution 36(2): 309-341.

Bremer, Stuart A., 1993. 'Democracy and Militarized Interstate Conflict, 1816-1965', International Interactions 18(3): 231-249.

Buzan, Barry, 1984. 'Economic Structure and International Security: The Limits of the Liberal Case', International Organization 38(4): 597-624.

Cardoso, Fernando \& Enzo Faletto, 1979. Dependence and Development in Latin America. (Translated by Marjory Mattingly Urquidi.) Berkeley, CA: University of California Press.

Choucri, Nazli \& Robert C. North, 1975. Nations in Conflict. San Francisco, CA: 


\section{Freeman.}

Copeland, Dale C., 1996. 'Economic Inter- dependence and War: A Theory of Trade Expectations', International Security 20(4): 5-41.

de Vries, Michael. S., 1990. 'Interdependence, Cooperation, and Conflict: An Empirical Analysis', Journal of Peace Research 27(4): 429-444.

Dixon, William J., 1993. 'Democracy and the Management of International Conflict', Journal of Conflict Resolution 37(1): 42-68.

Dixon, William J., 1994. 'Democracy and the Peaceful Settlement of International Conflict', American Political Science Review 88(1):14-32.

Domke, William, 1988. War and the Changing Global System. New Haven, CT: Yale University Press.

Doyle, Michael W., 1986. 'Liberalism and World Politics', American Political Science Review 80(4): 1151-1169.

Doyle, Michael W., 1997. Ways of War and Peace: Realism, Liberalism, and Socialism. New York: W. W. Norton.

Farber, Henry S. \& Joanne Gowa, 1995. 'Polities and Peace', International Security 20(2):123-146.

Gartzke, Erik, 1998. 'Kant We All Just Get Along? Opportunity, Willingness, and the Origins of the Democratic Peace', American Journal of Political Science 42(1): 1-27.

Gasiorowski, Mark J., 1986. 'Economic Inter- dependence and International Conflict: Some Cross-national Evidence', International Studies Quarterly 30(1): 23-38.

Gasiorowski, Mark J. \& Solomon W. Polachek, 1982. 'Conflict and Interdependence: EastWest Trade and Linkages in the Era of Detente', Journal of Conflict Resolution 26(4):709-729.

Gochman, Charles S. \& Zeev Maoz, 1984. 'Militarized Interstate Disputes, 1816-1976', Journal of Conflict Resolution 28(4): 585-615.

Gowa, Joanne, 1994. Allies, Adversaries, and Inter-national Trade. Princeton, NJ: Princeton University Press.

Gowa, Joanne, 1999. Ballots and Bullets: The Elusive Democratic Peace. Princeton, NJ: Princeton University Press.

Haas, Ernst B., 1958. The Uniting of Europe: Political, Social, and Economic Forces:1950-1957. Stanford, CA: Stanford University Press.

Hegre, Håvard, 1998. 'Does Trade Promote Peace?', paper presented at the Annual Meeting of the Peace Science Society (Inter- national), Rutgers University, New Brunswick, NJ, 16-18 October.

Hirschman, Albert O., 1945. National Power and the Structure of Foreign Trade. Berkeley \& Los Angeles, CA: University of California Press.

Hobson, John A., [1902] 1993. 'The Economic and Financial Taproots of Imperialism', in Paul Viotti \& Mark Kauppi, eds, International Relations Theory: Realism Pluralism and Globalism, 2nd edn. Englewood Cliffs, NJ: Prentice Hall (476-490).

Jones, Daniel M.; Stuart A. Bremer \& J. David Singer, 1996. 'Militarized Interstate Disputes,1816-1992: Rationale, Coding Rules, and Empirical Patterns', Conflict Management and Peace Science 15(2): 163-213.

Jones, E. Terrence, 1971. Conducting Political Research. New York: Harper \& Row.

Kant, Immanuel, [1795] 1969. Perpetual Peace (Reprint). New York: Columbia 
University Press.

King, Gary \& Langche Zeng, 2000. Inference in Case-Control Studies with Limited Auxiliary Information (http://gking.harvard.edu/ preprints.shtml\#1s) (downloaded 20 March 2000).

Lake, David A., 1992. 'Powerful Pacifists: Democratic States and War', American Political Science Review 86(1): 24-37.

Layne, Christopher, 1994. 'Kant or Cant: The Myth of the Democratic Peace', International Security 19(2): 5-49.

Lenin, Vladimir I., [1939] 1990. Imperialism, the Highest Stage of Capitalism. New York: International.

Levy, Jack S., 1989. 'The Causes of War: A Review of Theories and Evidence', in Philip E. Tetlock, Jo L. Husbands, Robert Jervis, Paul C. Stern \& Charles Tilly, eds, Behavior, Society, and Nuclear War, Volume 1. New York: Oxford University Press (209-333).

Lowi, Theodore J., 1964. 'American Business, Public Policy, Case-Studies, and Political Theory', World Politics 16(4): 677-715.

Lowi, Theodore, J., 1967. 'Making Democracy Safe for the World: National Politics and Foreign Policy', in James N. Rosenau, ed., Domestic Sources of Foreign Policy. New York: Free Press (295-331).

McMillan, Susan M., 1997. 'Interdependence and Conflict', Mershon International Studies Review 41(1): 33-58.

Mansbach, Richard W. \& John A. Vasquez,

1981. In Search of Theory: A New Paradigm for Global Politics. New York: Columbia University Press.

Maoz, Zeev \& Bruce Russett, 1993. 'Normative and Structural Causes of the Democratic Peace, 1946-1986', American Political Science Review 87(3): 624-638.

Mearsheimer, John J., 2002. 'Why We Will Soon Miss the Cold War', in Richard K. Betts, ed., Conflict After the Cold War, 2nd edn. New York: Longman (17-32) (http://www. theatlantic.com/politics/foreign/mearsh.htm).

Mitrany, David, 1946. A Working Peace System: An Argument for the Functional Development of International Organization. London: National Peace Council Pamphlet No. 40.

Morgan, T. Clifton \& Sally Howard Campbell,1991. 'Domestic Structure, Decisional Constraints, and War: So Why Kant Democracies Fight?', Journal of Conflict Resolution 35(2):187-211.

Morgan, T. Clifton \& Valerie L. Schwebach, 1992. 'Take Two Democracies and Call Me in the Morning: A Prescription for Peace?', Inter- national Interactions 17(3): 305-320.

Morgenthau, Hans J., 1985. Politics Among Nations: The Struggle for Power and Peace, 6th edn (revised by Kenneth Thompson). New York: Knopf.

Oneal, John R.; Frances Oneal, Zeev Maoz \& Bruce Russett, 1996. 'The Liberal Peace: Interdependence, Democracy and Inter- national Conflict, 1950-1986', Journal of Peace Research 33(1): 11-28.

Oneal, John R. \& Bruce Russett, 1997. 'The Classical Liberals Were Right: Democracy, Interdependence, and Conflict, 1950-1985', International Studies Quarterly 41(2): 267-294.

Oneal, John R. \& Bruce Russett, 1999a. 'Assessing the Liberal Peace with Alternative Specifications: Trade Still Reduces Conflict', Journal of Peace Research 36(4): 423-442. 
Oneal, John R. \& Bruce Russett, 1999b. 'Is the Liberal Peace Just an Artifact of Cold War Interests? Assessing Recent Critiques', Inter- national Interactions 25(3): 213-241.

Oneal, John R. \& Bruce Russett, 1999c. 'The Kantian Peace: The Pacific Benefits of Democracy, Interdependence, and International Organizations, 1885-1992', World Politics 52(1): 1-37.

Oren, Ido, 1995. 'The Subjectivity of the 'Democratic' Peace: Changing U.S. Perceptions of Imperial Germany', International Security 20(2): 147-184.

Owen, John M., 1994. 'How Liberalism Produces Democratic Peace', International Security 19(2): 87-125.

Papayoanou, Paul, 1996. 'Interdependence, Institutions, and the Balance of Power: Britain, Germany, and World War I', International Security 20(4): 42-76.

Polachek, Solomon W., 1980. 'Conflict and Trade', Journal of Conflict Resolution 24(1): 55-78.

Ray, James Lee, 1993. 'Wars Between Democracies: Rare, or Nonexistent?', International Interactions 18(3): 251-276.

Ripsman, Norrin \& Jean-Marc Blanchard, 1996.

'Commercial Liberalism Under Fire: Evidence from 1914 and 1936', Security Studies $6(2): 4-50$.

Rosecrance, Richard, 1986. The Rise of the Trading State: Commerce and Conquest in the Modern World. New York: Basic.

Rosenau, James N., 1966. 'Pre-Theories and

Theories of Foreign Policy', in R. Barry Farrell, ed., Approaches to Comparative and International Politics. Evanston, IL: Northwestern University Press (27-92).

Rummel, Rudolph J., 1983. 'Libertarianism and International Violence', Journal of Conflict Resolution 27(1): 27-71.

Rummel, Rudolph J., 1985. 'Libertarian Proposi- tions on Violence Within and Between Nations: A Test Against Published Research Results', Journal of Conflict Resolution 29(3):419-455.

Russett, Bruce, 1993. Grasping the Democratic Peace: Principles for a Post-Cold War World. Princeton, NJ: Princeton University Press.

Russett, Bruce, John R. Oneal \& David R. Davis, 1998. 'The Third Leg of the Kantian Tripod for Peace: International Organizations and Militarized Disputes, 1950-85', International Organization 52(3): 441-467.

Sayrs, Lois W., 1989. 'Trade and Conflict Revisited: Do Politics Matter?', International Interactions 15(2): 155-175.

Small, Melvin \& J. David Singer, 1976. 'The War Proneness of Democratic Regimes,1816-1965', Jerusalem Journal of International Relations 1(1): 50-69.

Spiro, David E., 1994. 'The Insignificance of the Liberal Peace', International Security 19(2):50-86.

Vasquez, John A., 1983. 'The Tangibility of Issues and Global Conflict: A Test of Rosenau's Issue Area Typology', Journal of Peace Research

20(2): 179-192.

Waltz, Kenneth, 1979. Theory of International

Politics. New York: Random House.

Wolfers, Arnold, 1962. Discord and Collaboration: Essays on International Politics. Baltimore, MD: Johns Hopkins Press. 
Zimmerman, William, 1973. 'Issue Area and Foreign Policy Process: A Research Note in Search of a General Theory', American Political Science Review 67(4): 1204-1212. 
Table I. Descriptive Statistics

\begin{tabular}{|c|c|c|c|c|c|}
\hline Variable & Observations & Mean & $\begin{array}{l}\text { Standard } \\
\text { deviation }\end{array}$ & Minimum & Maximum \\
\hline Dispute onset & 834,764 & .001 & .035 & $\mathbf{0}$ & 1 \\
\hline Lower trade-to-GDP ratio $t-1$ & 735,033 & .000 & .002 & $\mathbf{0}$ & .205 \\
\hline Higher trade-to-GDP ratio $t-1$ & 735,033 & .003 & .015 & $\mathbf{0}$ & 1.215 \\
\hline Joint democracy $t-1$ & 699,289 & 76.818 & 111.622 & $\mathbf{0}$ & 400 \\
\hline Contiguity $t-1$ & 820,402 & .042 & .201 & $\mathbf{0}$ & 1 \\
\hline Log distance $t-1$ & 798,807 & 8.221 & .797 & 1.872 & 9.423 \\
\hline Major power $t-1$ & 820,402 & .083 & .276 & $\mathbf{0}$ & 1 \\
\hline Allied $t-1$ & 799,642 & .125 & .331 & $\mathbf{0}$ & 1 \\
\hline Log capability ratio $t-1$ & 762,882 & 2.060 & 1.588 & .000 & 10.961 \\
\hline Symbolic political relations $t-1$ & 823,513 & .002 & .041 & $\mathbf{0}$ & 1 \\
\hline Economic relations $t-1$ & 823,513 & .002 & .043 & $\mathbf{0}$ & 1 \\
\hline Military/strategic relations $t-1$ & 823,513 & .003 & .051 & $\mathbf{0}$ & 1 \\
\hline Cultural/scientific relations $t-1$ & 823,513 & .001 & .024 & $\mathbf{0}$ & 1 \\
\hline $\begin{array}{l}\text { Physical environment/natural } \\
\text { resources } t-1\end{array}$ & 823,513 & .000 & .01 & $\mathbf{0}$ & 1 \\
\hline $\begin{array}{l}\text { Human environment/ } \\
\text { demographic/ethnic affairs } t-1\end{array}$ & 823,513 & .001 & .028 & $\mathbf{0}$ & 1 \\
\hline $\begin{array}{l}\text { Political order/political relations/ } \\
\text { law/organization } t-1\end{array}$ & 823,513 & .008 & 091 & $\mathbf{0}$ & 1 \\
\hline
\end{tabular}


Table II. The Onset of Militarized Interstate Disputes, 1950-78

\begin{tabular}{lrccc} 
Variable & Coefficient & Standard error & $Z$ & $\begin{array}{c}\text { Significance } \\
p>/ z /\end{array}$ \\
\hline Lower trade-to-GDP ratio $t-1$ & -185.971 & 66.415 & -2.8 & 0.005 \\
Higher trade-to-GDP ratio $t-1$ & 4.768 & 2.36 & 2.021 & 0.043 \\
Joint democracy $t-1$ & -0.001 & 0.001 & -1.272 & 0.203 \\
Contiguity $t-1$ & 2.381 & 0.274 & 8.683 & 0 \\
Log distance $t-1$ & -0.474 & 0.074 & -6.441 & 0 \\
Major power $t-1$ & 1.933 & 0.288 & 6.723 & 0 \\
Allied $t-1$ & -0.418 & 0.186 & -2.243 & 0.025 \\
Log capability ratio $t-1$ & -0.277 & 0.064 & -4.306 & 0 \\
& & & & \\
Peaceyears & -0.613 & 0.070 & -8.795 & 0 \\
Spline1 & -0.013 & 0.002 & -5.447 & 0 \\
Spline2 & 0.009 & 0.002 & 4.293 & 0 \\
Spline3 & -0.002 & 0.001 & -2.698 & 0.007 \\
Constant & -1.187 & 0.657 & -1.807 & 0.071 \\
\hline
\end{tabular}

Chi-square $=2239.42 ;$ chi-square $\mathrm{df}=12$; significance level $=0.0000 ; \log$ likelihood $=-4033.5278 ;$ pseudo $R^{2}: 0.3244$; $\mathrm{N}=\mathbf{6 2 1 , 7 6 8}$ 
Table III. Hypothetical Example of Change in Temporal Aggregation

Full year

\begin{tabular}{l|c|c|}
\multicolumn{1}{c}{} & \multicolumn{1}{c}{$\begin{array}{c}\text { Non-democratic } \\
\text { dyad }\end{array}$} & \multicolumn{1}{c}{$\begin{array}{c}\text { Democratic } \\
\text { dyad }\end{array}$} \\
\cline { 2 - 3 } MID & 20 & 0 \\
\cline { 2 - 3 } No MID & 70 & 10 \\
\cline { 2 - 3 } & &
\end{tabular}

Phi $=.167$
Quarter-year

Non-democratic Democratic dyad dyad

MID

No MID

\begin{tabular}{|c|c|}
\hline 20 & 0 \\
\hline 340 & 40 \\
\hline
\end{tabular}

Phi $=.076$

Table IV. Effect of Issue Area on Onset of Militarized Interstate Disputes, 1950-78

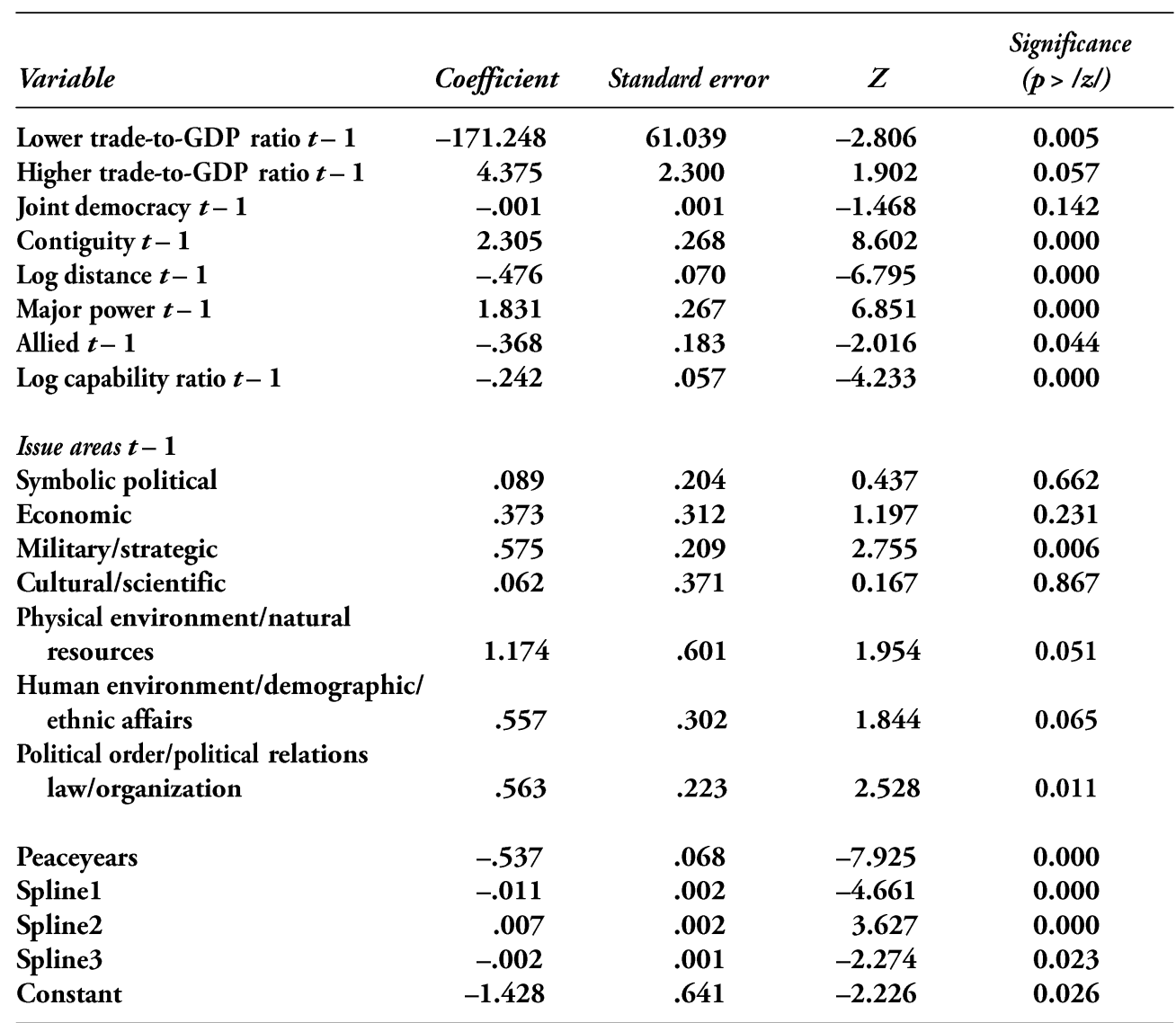

Chi-square $=3612.76$; chi-square $\mathrm{df}=19$; significance level $=0.0000 ; \log$ likelihood $=-3992.8632 ;$ pseudo $R^{2}: 0.3313$; $\mathrm{N}=\mathbf{6 2 1 , 7 6 7}$ 
Table V. Probabilities and Relative Risk of Disputes

\begin{tabular}{lcc}
\hline Condition at $t$ & $\operatorname{Pr}(M I D)$ at $t+1$ & Relative risk \\
\hline Baseline & .000 & \\
Baseline + military & .001 & 1.78 \\
Baseline + political order & .001 & 1.76 \\
\hline
\end{tabular}


Table VI. Effect of Issue Area and Issue Area Interactions on Onset of Militarized Interstate Disputes, 1950-78

\begin{tabular}{|c|c|c|c|c|}
\hline Variable & Coefficient & Standard error & $Z$ & $\begin{array}{l}\text { Significance } \\
(p>/ z /)\end{array}$ \\
\hline Lower trade-to-GDP ratio $t-1$ & -155.662 & 58.681 & -2.653 & 0.008 \\
\hline Higher trade-to-GDP ratio $t-1$ & 5.157 & 2.179 & 2.367 & 0.018 \\
\hline Joint democracy $t-1$ & -.002 & .001 & -1.644 & 0.100 \\
\hline Contiguity $t-1$ & 2.296 & .266 & 8.624 & 0.000 \\
\hline Log distance $t-1$ & -.473 & .070 & -6.759 & 0.000 \\
\hline Major power $t-1$ & 1.843 & .262 & 7.024 & 0.000 \\
\hline Allied $t-1$ & -.364 & .183 & -1.990 & 0.047 \\
\hline Log capability ratio $t-1$ & -.243 & .056 & -4.315 & 0.000 \\
\hline \multicolumn{5}{|l|}{ Issue areas $t-1$} \\
\hline Symbolic political & .049 & .214 & 0.229 & 0.819 \\
\hline Economic & .402 & .317 & 1.269 & 0.204 \\
\hline Military/strategic & .632 & .287 & 2.201 & 0.028 \\
\hline Cultural/scientific & .11 & .366 & 0.300 & 0.764 \\
\hline $\begin{array}{l}\text { Physical environment/natural } \\
\text { resources }\end{array}$ & 1.130 & .602 & 1.876 & 0.061 \\
\hline $\begin{array}{l}\text { Human environment/demographic/ } \\
\text { ethnic affairs }\end{array}$ & .501 & .305 & 1.641 & 0.101 \\
\hline Political order/political relations & & & & \\
\hline law/organization & .581 & .289 & 2.014 & 0.044 \\
\hline \multicolumn{5}{|l|}{$\begin{array}{l}\text { Significant issue area interaction } t-1 \\
\text { (Military/strategic)(Higher }\end{array}$} \\
\hline $\begin{array}{l}\text { trade-to-GDP ratio) } \\
\text { (Military/strategic)(Lower }\end{array}$ & -17.068 & 10.915 & -1.564 & 0.118 \\
\hline trade-to-GDP ratio) & -141.681 & 165.582 & -0.856 & 0.392 \\
\hline (Military/strategic)(Joint democracy) & .001 & .002 & 0.499 & 0.618 \\
\hline $\begin{array}{l}\text { (Political order/political relations } \\
\text { law/organization) (Higher }\end{array}$ & & & & \\
\hline trade-to-GDP ratio) & -6.781 & 8.179 & -0.829 & 0.407 \\
\hline $\begin{array}{l}\text { (Political order/political relations } \\
\text { law/organization) (Lower }\end{array}$ & & & & \\
\hline $\begin{array}{l}\text { trade-to-GDP ratio) } \\
\text { (Political order/political relations } \\
\text { law/organization) (Joint }\end{array}$ & -90.460 & 120.049 & -0.754 & 0.451 \\
\hline democracy) & .001 & .002 & 0.680 & 0.497 \\
\hline Peaceyears & -.536 & .068 & -7.910 & 0.000 \\
\hline Spline1 & -.011 & .002 & -4.639 & 0.000 \\
\hline Spline2 & .007 & .002 & 3.610 & 0.000 \\
\hline Spline3 & -.002 & .001 & -2.266 & 0.023 \\
\hline Constant & -1.445 & .638 & -2.263 & 0.024 \\
\hline
\end{tabular}

Chi-square = 4011.38; chi-square $\mathrm{df}=25$; significance level = 0.0000; $\log$ likelihood = 3988.4174; pseudo $R^{2}: 0.3320$; $\mathrm{N}=621,767$ 